\title{
Hydrocarbon reservoir volume estimation using 3-D seismic and well log data over an X-field, Niger Delta Nigeria
}

\author{
C. N. Nwankwo $\cdot$ M. Ohakwere-Eze • \\ J. O. Ebeniro
}

Received: 20 April 2013/ Accepted: 2 January 2015/Published online: 28 January 2015

(c) The Author(s) 2015. This article is published with open access at Springerlink.com

\begin{abstract}
This study delineates and maps the hydrocarbon-bearing reservoir HD2000 from surface seismic sections and well $\operatorname{logs}$ within the depth interval of $5,700 \mathrm{ft}$ $(1,737 \mathrm{~m})$ and $6,200 \mathrm{ft}(1,890 \mathrm{~m})$. The objective is to establish the geometry, reservoir distribution, delineate hydrocarbon-bearing reservoirs from surface seismic sections and well logs. In this process, a 3-D structural interpretation and estimation of the volume of hydrocarbon in place of the reservoirs was carried out. Well-to-seismic tie revealed that hydrocarbon-bearing reservoirs were associated with direct hydrocarbon indicators (bright spots and dim spots) on the seismic sections. Two horizons were studied (HD2 and HD2_version2) and several faults mapped for the purpose of carrying out 3-D subsurface structural interpretation. This was used in generating the time structure maps. From the maps, it was observed that the principal structure responsible for hydrocarbon entrapment in the field was the anticlinal structure at the center of the field which tied to the crest of the rollover structure seen on the seismic sections. Check shots from the control well were used to create a velocity model from which the time to depth conversion was made. Horizon slice taken shows the reservoir spans a thickness of $400 \mathrm{ft}$. Direct hydrocarbon indicators were used to map the reservoir boundary. They were seen on the reflection amplitude maps as high amplitude zones (bright spots) and low amplitude zones (dim spots). Reservoir area extent estimated by square grid
\end{abstract}

C. N. Nwankwo $(\bowtie) \cdot$ J. O. Ebeniro

Physics Department, University of Port Harcourt, Port Harcourt, Nigeria

e-mail: cyrilnn@yahoo.com

M. Ohakwere-Eze

Physics Department (Earth Sciences), Salem University, Lokoja, Nigeria template method revealed that reservoir HD2000 had an area estimate of $5.29 \mathrm{~km}^{2}$. The results show the effectiveness of the estimation techniques in the lateral prediction of reservoir properties, discriminating litho-fluid and determining the porosity, saturation, net-to-gross ratio, and moreover the reserve volume. Hydrocarbon saturation varied between 0.64 and 0.65 , while effective porosity varied between 0.31 and 0.32 . Estimation of the volume of hydrocarbon in place revealed that the delineated reservoir HD2000 contained an estimate of 776,545,418.22 barrels $\left(123,460,855.4 \mathrm{~cm}^{3}\right)$ of hydrocarbon which shows great potential of considerable size.

Keywords Hydrocarbon - Reservoir - Volume - Seismic . Well logs $\cdot$ Structure $\cdot$ Horizon

\section{Introduction}

Almost all oil and gas produced today comes from accumulations in the pore spaces of reservoir rocks like sandstone, limestone or dolomites. The amount of oil or gas contained in a unit volume of such a reservoir is the product of its porosity and the hydrocarbon saturation. To quantify the hydrocarbon in place of a reservoir, knowledge of the character and extent of such a reservoir is needed. Information required for volume analysis are the thickness, pore space, and areal extent of the reservoir (Ihianle et al. 2013). Other input parameters are shale volume, saturation, net to gross, and shale volume values (Edward and Santogrossi 1990). In the majority of reservoir development projects, the description of the reservoir is achieved through integrating well information and seismic data. The available well information provides calibration points and the lateral variations in the seismic 
attributes which provide details, on the distribution of the reservoir properties away from well control.

This study is based on the use of wireline logs data and 3-D seismic data to analyze and estimate prospective reservoir volume of sand bodies in an oil field in the Niger Delta region of Nigeria. The objective is to determine the reservoir rock attributes and to use such valuable information to compute the reservoir volume of the study area. The reservoir geophysical parameters (porosity and hydrocarbon saturation) were computed for hydrocarbon pore volume (HCPV) determination; hence the existence of economically producible hydrocarbon reservoirs was established.

\section{Geologic setting of the study area}

The precise location of the study area was not disclosed in line with current practices by petroleum industries in Nigeria. However, the study area is located within the oil rich province of the Niger Delta (Fig. 1). The delta is a sedimentary structure formed as a complex regressive offlap of clastic sediments ranging in thickness from 9,000 to 12,000 m (Etu-Efeotor 1997). Only one petroleum system called the Tertiary Niger (Akata-Agbada) Petroleum System has been identified (Kulke 1995). The geology, stratigraphy, and structure of the Niger delta basin have been extensively discussed by several authors (Short and Stauble
1967; Merki 1970; Weber and Daukoru 1975; Avbovbo 1978; Evamy et al. 1978; Whiteman 1982; Owoyemi and Wills 2006; Bilotti and Shaw 2005). The Niger Delta basin is situated on the continental margin of the Gulf of Guinea between latitude $3^{\circ}$ and $6^{\circ} \mathrm{N}$ and longitude $5^{\circ}$ and $8^{\circ} \mathrm{E}$. The areal extent of the Delta is about $75,000 \mathrm{~km}^{2}$ with a clastic fill of about $12,000 \mathrm{~m}$. The Niger Delta province is ranked the twelfth richest petroleum resources with $2.2 \%$ of the world's discovered oil and $1.4 \%$ of world's discovered gas by the US Geological Survey's World Energy Assessment (Klett et al. 1997).

The Niger Delta consists of three broad formations, the Benin, Agbada, and Akata Formations (Short and Stauble 1967). The Benin Formation is the shallowest of the sequence and consists predominantly of fresh water-bearing continental sands and gravels. The Agbada Formation underlies the Benin Formation and consists primarily of sand and shale, and is of fluviomarine origin. It is the main hydrocarbon-bearing window. The formation is about 3,700 m thick and consists of Paralic Siliclastics; it forms a good representation of the actual deltaic sequence. This is the seat of most oil reservoirs and center of over pressures. The Akata Formation is composed of shales, clays, and silts and lies at the base of the Niger Delta Sequence. It is of marine origin. They contain a few streaks of sand, possibly of turbiditic origin. The thickness of this sequence is not known for certain, but may reach $7,000 \mathrm{~m}$ in the central part of the delta (Short and Stauble 1967).

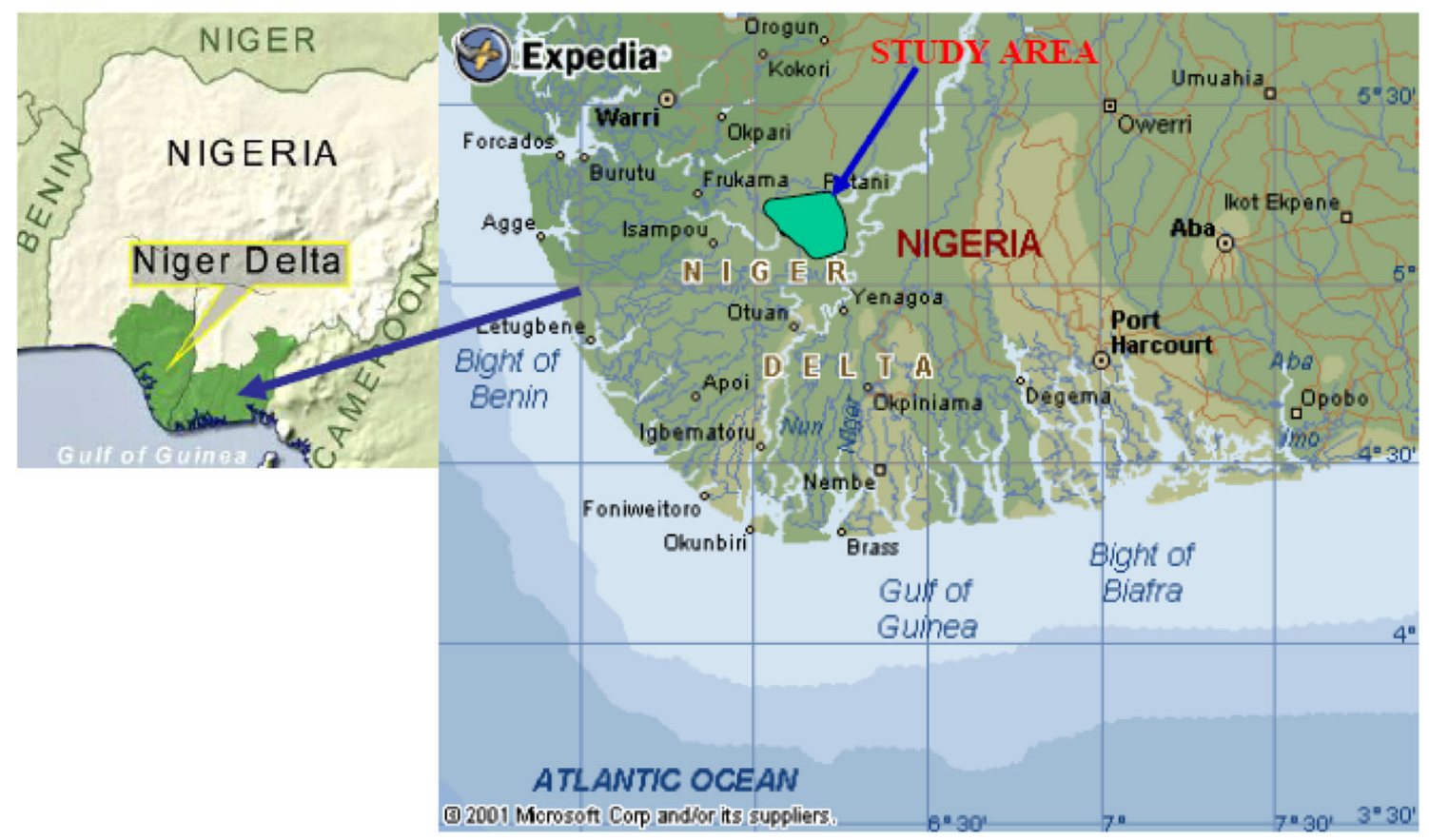

Fig. 1 Map of Nigeria, showing the study area $\left({ }^{\circledR} 2001\right.$ Microsoft Corp) 


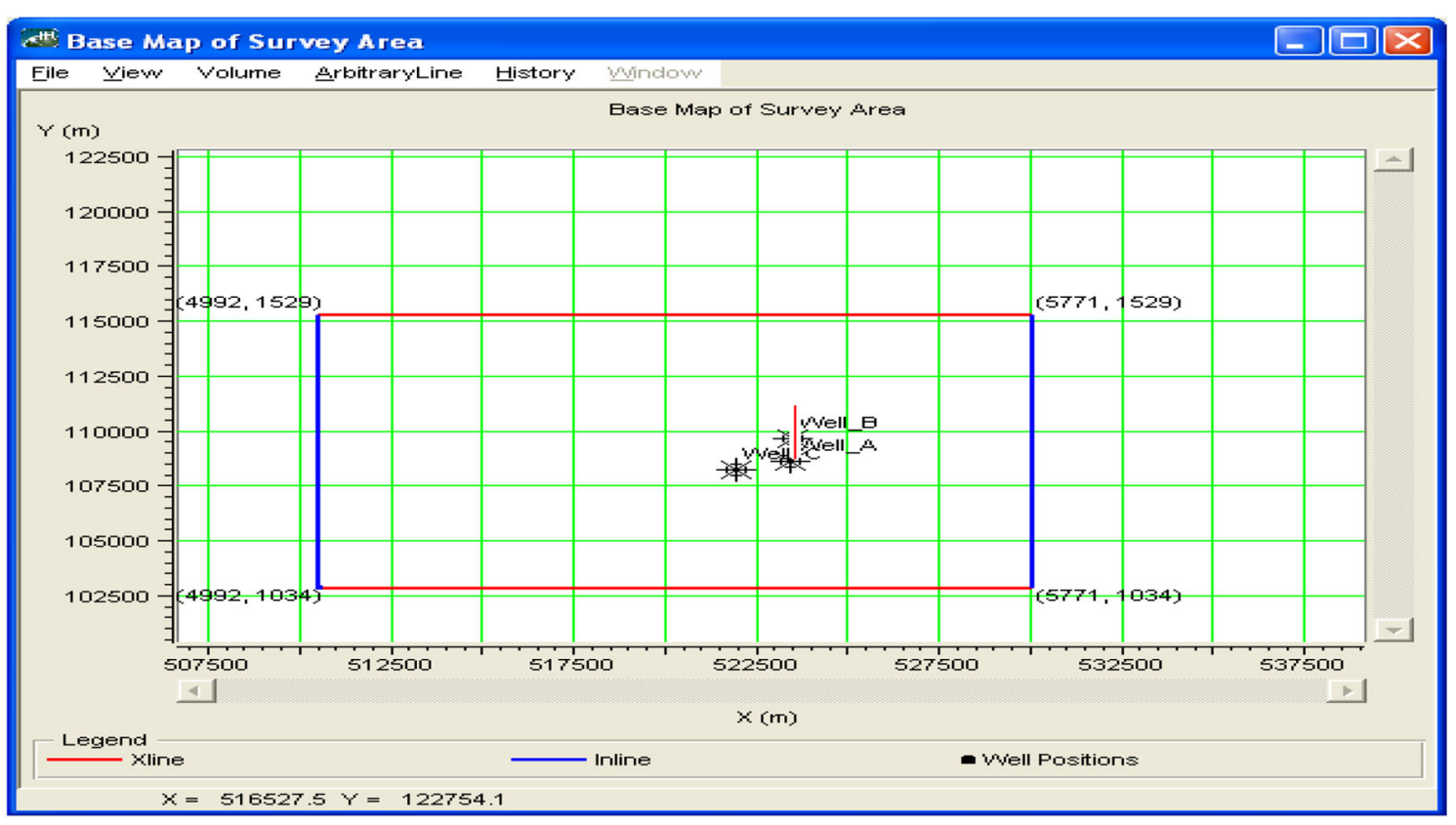

Fig. 2 Base map of the study area

\section{Methodology}

Several steps of analysis were adopted to evaluate the sand bodies of the area under investigation. Multiple 3-D postseismic and digital well log data in LAS format were provided for three wells from an x-oil field offshore Niger Delta. The data used in this work are well log data and multiple 3-D post-stack seismic data from an offshore area in Niger Delta oil field. The data consist of suites of well logs from wells A, B, C, a base map (Fig. 2) and a 3-D seismic data. The wire line log data comprises of sonic log, density, self potential (SP), resistivity $\log$, caliper $\log$, porosity $\log$, shale volumetric log, and gamma ray log (Table 1). The zone of interest is typically a sand/shale/ sand sequence.

HAMPSON RUSSEL software was used for data analysis. The program has the capacity of integrating

Table 1 Table showing available log suite for each well

\begin{tabular}{lll}
\hline Well A & Well B & Well C \\
\hline Density & Density & Density \\
Gamma ray & Gamma ray & Gamma ray \\
P-wave & P-wave & P-wave \\
Resistivity & Resistivity & Resistivity \\
& Caliper & Caliper \\
& Porosity & \\
& Shale volume &
\end{tabular}

geology with Well and seismic data. The composite geophysical well logs, seismic sections, and check shot data were imported into the interactive HAMPSON RUSSELL workstation. The relevant wireline log signatures were employed to identify hydrocarbon-bearing reservoirs and the work flow adopted is according to the chart in Fig. 3.

Volume estimation

In calculating the volume of hydrocarbon in place, the gross rock volume, net-to-gross $(\mathrm{n} / \mathrm{G})$ ratio, porosity, and the hydrocarbon saturation of each zones were considered. The volume of hydrocarbon in place (hydrocarbon pore volume, HCPV) was calculated from Eq. 1 as used by Aly (1989):

$\mathrm{HCPV}=V \Phi N / G\left(1-S_{\mathrm{W}}\right)$

Where $V=$ Volume of hydrocarbon; which equals the product of reservoir area extent $(A)$ and its thickness $(h)$, $\Phi=$ Porosity, $S_{\mathrm{W}}=$ water saturation, $N / G=$ ratio of netto-gross thickness of the reservoir as obtained from the gamma ray $\operatorname{logs}$ or the sand volume within the two geological Horizons or markers.

However N/G has been assumed to be $95 \%$ due to the almost complete sand volume in the reservoir HD2000. Table 2 shows the model equations employed in computing other volumetric parameters. 
Fig. 3 Flow chart illustrating the methodology

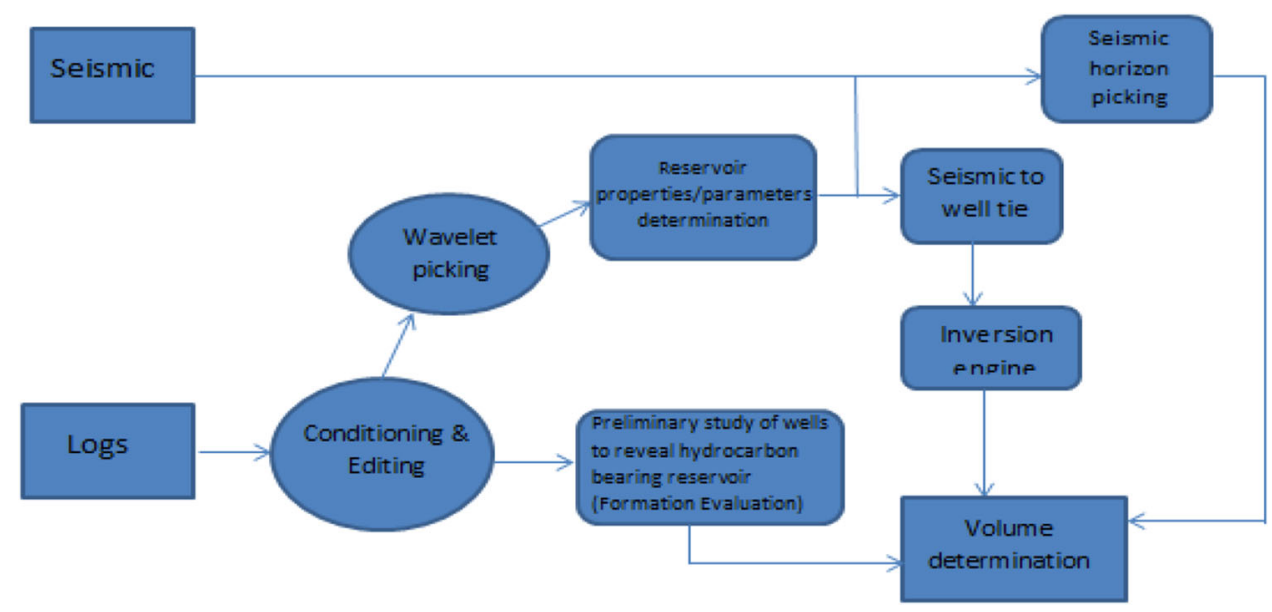

Table 2 Quick view of volumetric equations used in calculations

\begin{tabular}{lc}
\hline Volume parameter equations and equalities \\
\hline Rock volume & $V_{\mathrm{R}}=A * h$ \\
\hline Pore volume & $V_{\mathrm{P}}=V_{\mathrm{R}} * \varphi=A * h * \varphi$ \\
Hydrocarbon pore & $V_{\mathrm{HCPV}}=V_{\mathrm{P}} *\left(S_{\mathrm{HC}}\right) * \mathrm{~N} / \mathrm{G}=A * h$ \\
volume & $* \varphi *\left(1-S_{\mathrm{W}}\right) * \mathrm{~N} / \mathrm{G}$ \\
& Where $\mathrm{S}_{\mathrm{HC}}=$ the hydrocarbon \\
& saturation of interest.
\end{tabular}

\section{Analysis of results}

\section{Well log interpretation}

Preliminary study on the well logs revealed one hydrocarbon-bearing reservoir HD 2000 with top HD2_V2 and base HD2 within depth interval of 5,280-8,250 ft for Well A, 5,000-7,500 ft for Well B, and 4,000-8500 ft for Well C. The wells exhibit a dominantly shale/sand/shale sequence, typical of the Niger Delta formation. The wells were analyzed in terms of fluid type and lithology. Shale lithology was delineated by the high gamma ray value. Regions of low gamma ray, high resistivity and low water saturation are mapped as sand lithology, which are also regions of high hydrocarbon saturation. The reservoir mapped areas of very low GR, high porosity, and low water saturation (Figs. 4, 5, 6).

Acoustic impedance volume

The acoustic impedance volume shown in Fig. 7 is a cross section of the base seismic data with inserted inline number 5506. A reduction in the impedance is as a result of production effect in the reservoir. Low water saturation section can be seen within the reservoir; which is indicative of a hydrocarbon charge zone.
The well locations exhibits relatively low acoustic impedance values within the square grid (Fig. 8). These low values of acoustic impedance are associated with hydrocarbon saturated sands; areas of high acoustic impedance are observed as a result of probable depleted zones (Fig. 9). As seen in Fig. 7, sandstone reservoir shows low velocity and low impedance. Checkshot from the control well was used to associate travel time (a measure of velocity) with each of a number of depths in the wells. Horizons HD2 and HD_version2 were tracked on these reflections, on both inlines and crosslines across the field to produce the time structure (isochron) maps. This then was used to produce and understand the velocity relationship between depths and two-way acoustic travel times (isopach map).

The depth structure map generated revealed that for reservoir HD2000, the depth from the top (HD2_version2) to the bottom (HD2) is estimated $400 \mathrm{ft}(121.92 \mathrm{~m})$.

\section{Rock attribute slice}

The rock attribute slices were subsequently extracted from the impedance volume. Changes in the rock attributes were evaluated for probable hydrocarbon prospects. It was observed that the computed porosity estimate in reservoir HD2000 varied from 0.31 to 0.32 (Fig. 10). Also, the hydrocarbon saturation estimated in reservoir HD2000 varied from 0.64 to 0.65 (Fig. 11).

\section{Volumetric}

The total area of a reservoir and its thickness are of considerable importance in determining if a reservoir is a commercial one or not. The more the area and thickness of a reservoir the greater its potential for oil and gas accumulations. However, there are reservoirs that produce substantial amounts of hydrocarbons that are not of 


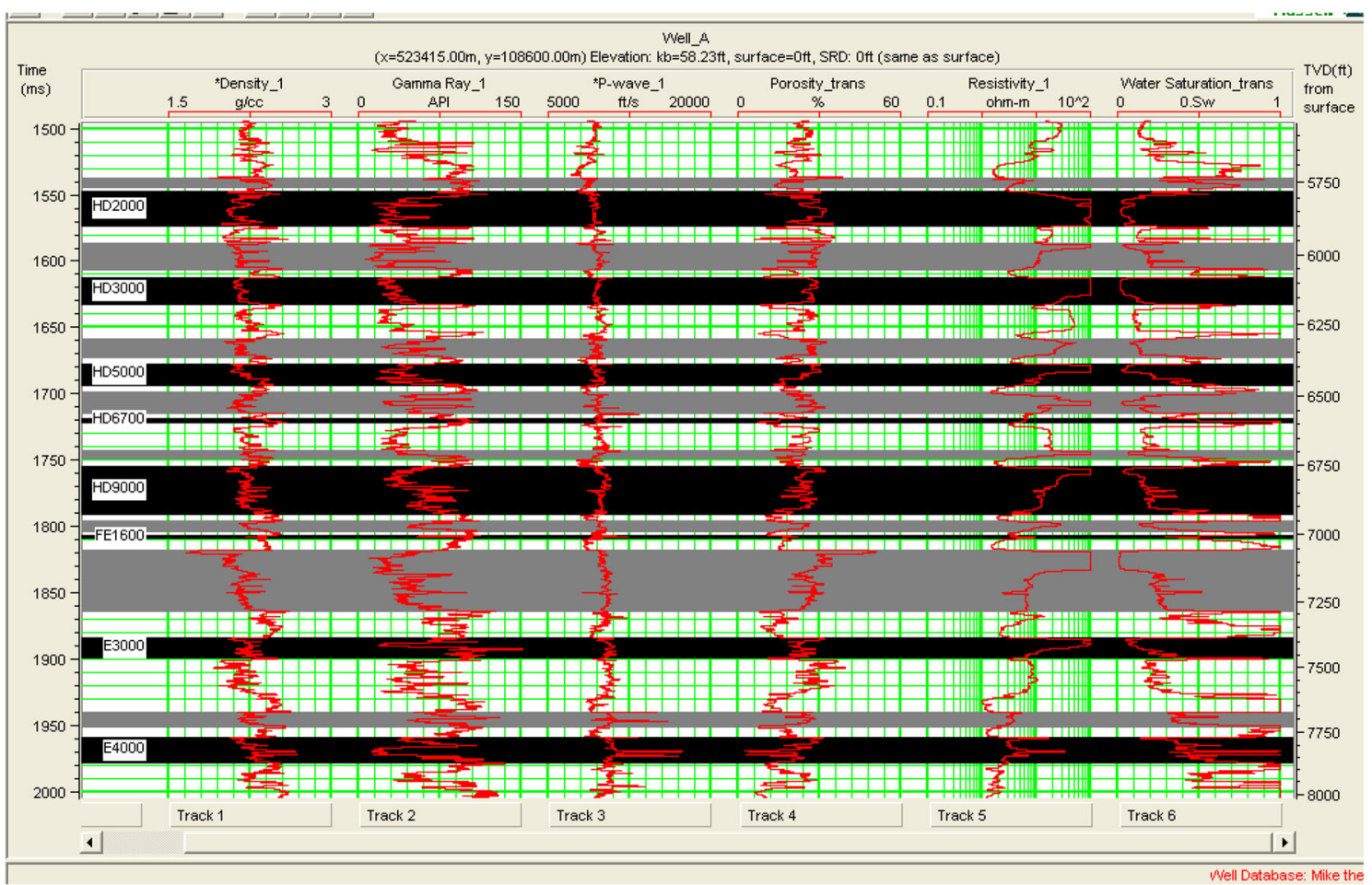

Fig. 4 Well A showing various log signatures and delineated HD2000 reservoir in black strip

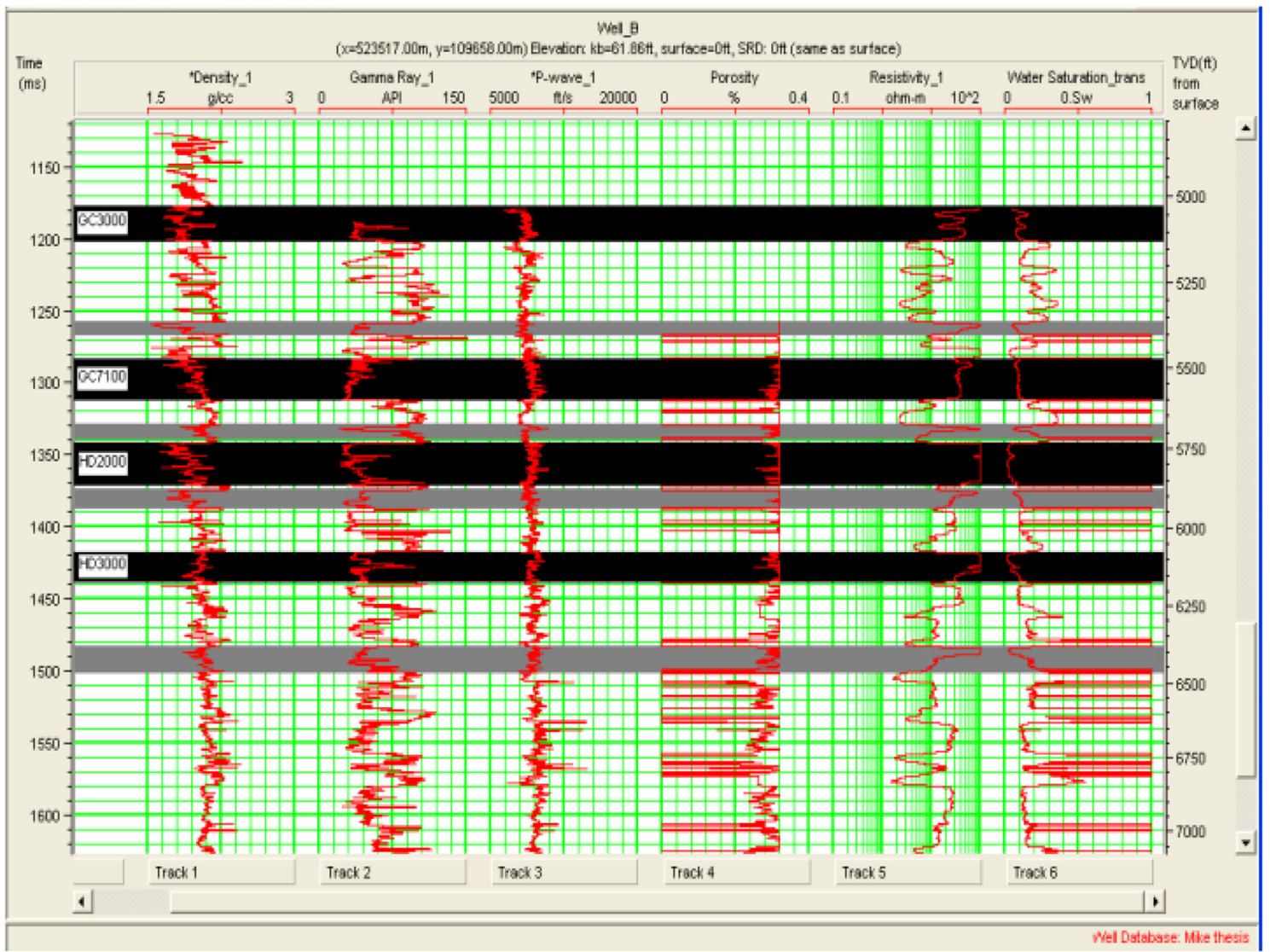

Fig. 5 Well B showing various log signatures and delineated HD2000 reservoir in black strip 


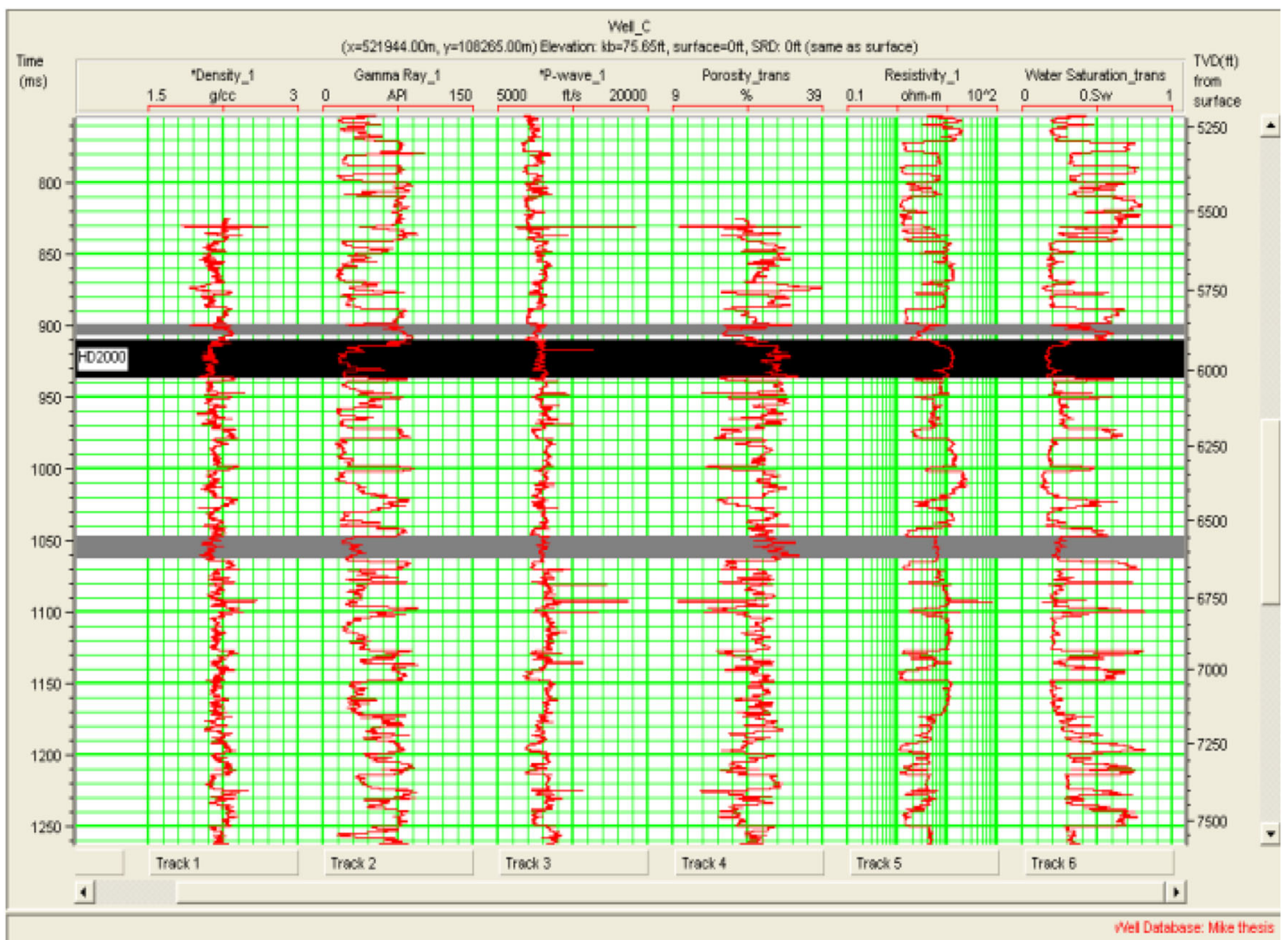

Fig. 6 Well $\mathbf{C}$ showing various log signatures and delineated reservoir in black strip

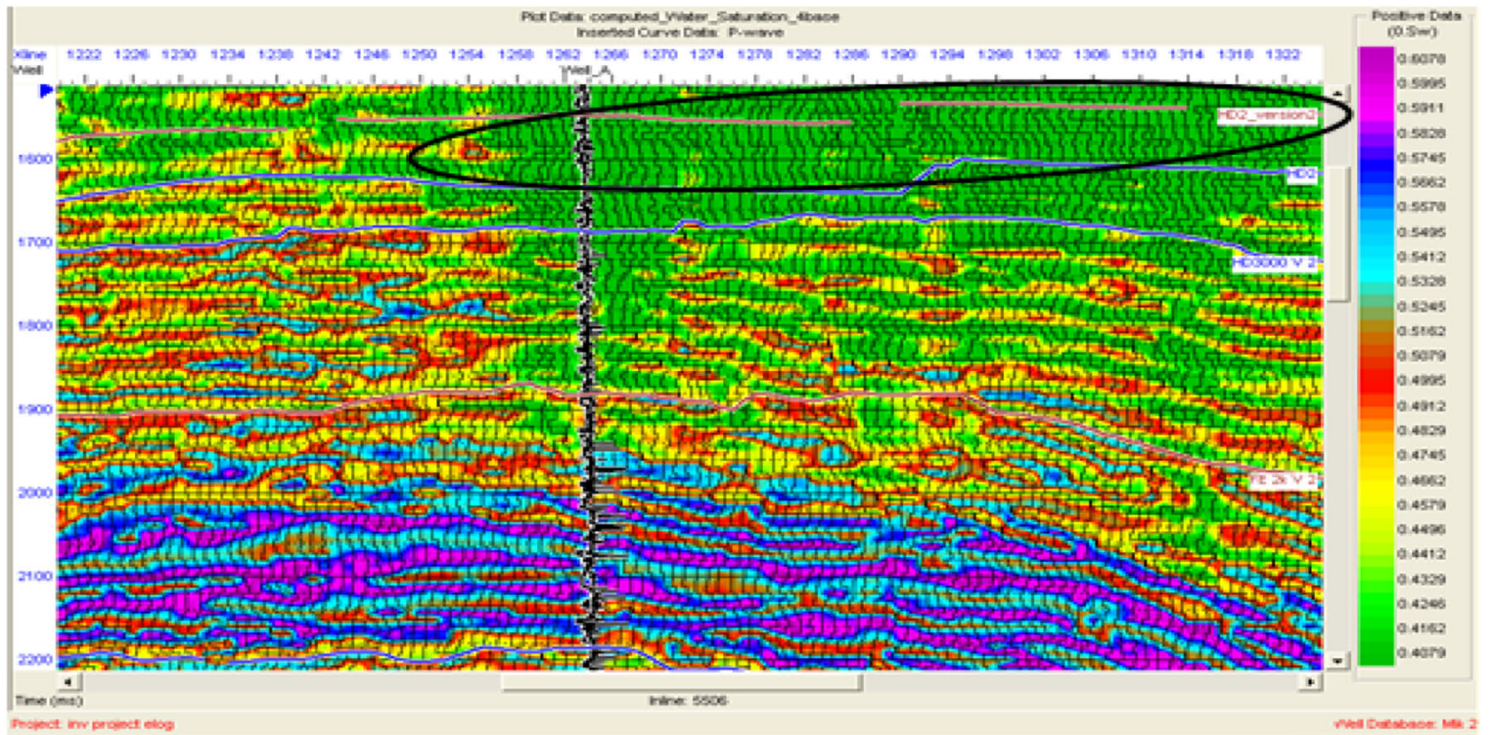

Fig. 7 Cross section of acoustic impedance of a seismic base with sphere showing the reservoir

considerable size. The surface area extent covered by the reservoir was estimated using the grid template method. Since the bright and dim spots are indicators of hydrocarbon presence, the lateral boundaries of these reservoirs were mapped from the amplitudes. The reflection amplitude maps were generated from horizons HD2 and HD2_version2 (Fig. 8) and the zone of anomalous high amplitude were used to map the boundaries of the reservoir 

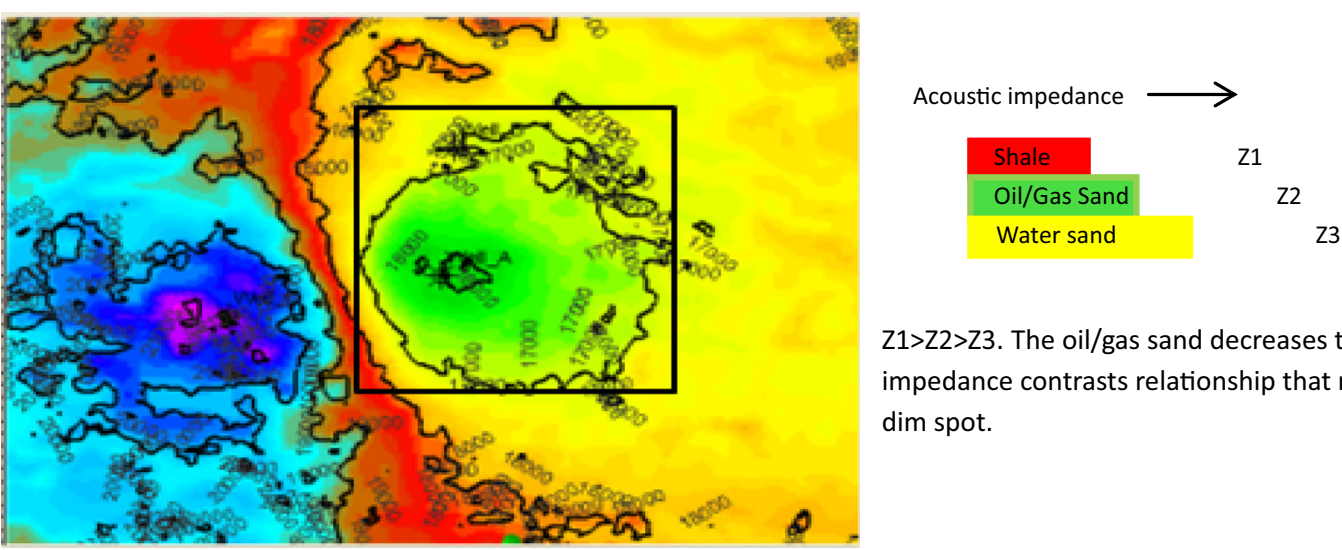

Z1>Z2>Z3. The oil/gas sand decreases the acoustic impedance contrasts relationship that results in a dim spot.

Fig. 8 Inverted acoustic impedance volume for slice HD2000 with a square grid template mapped on the wells

Fig. 9 Volume display showing areas of low acoustic impedance signifying sand body about that depth
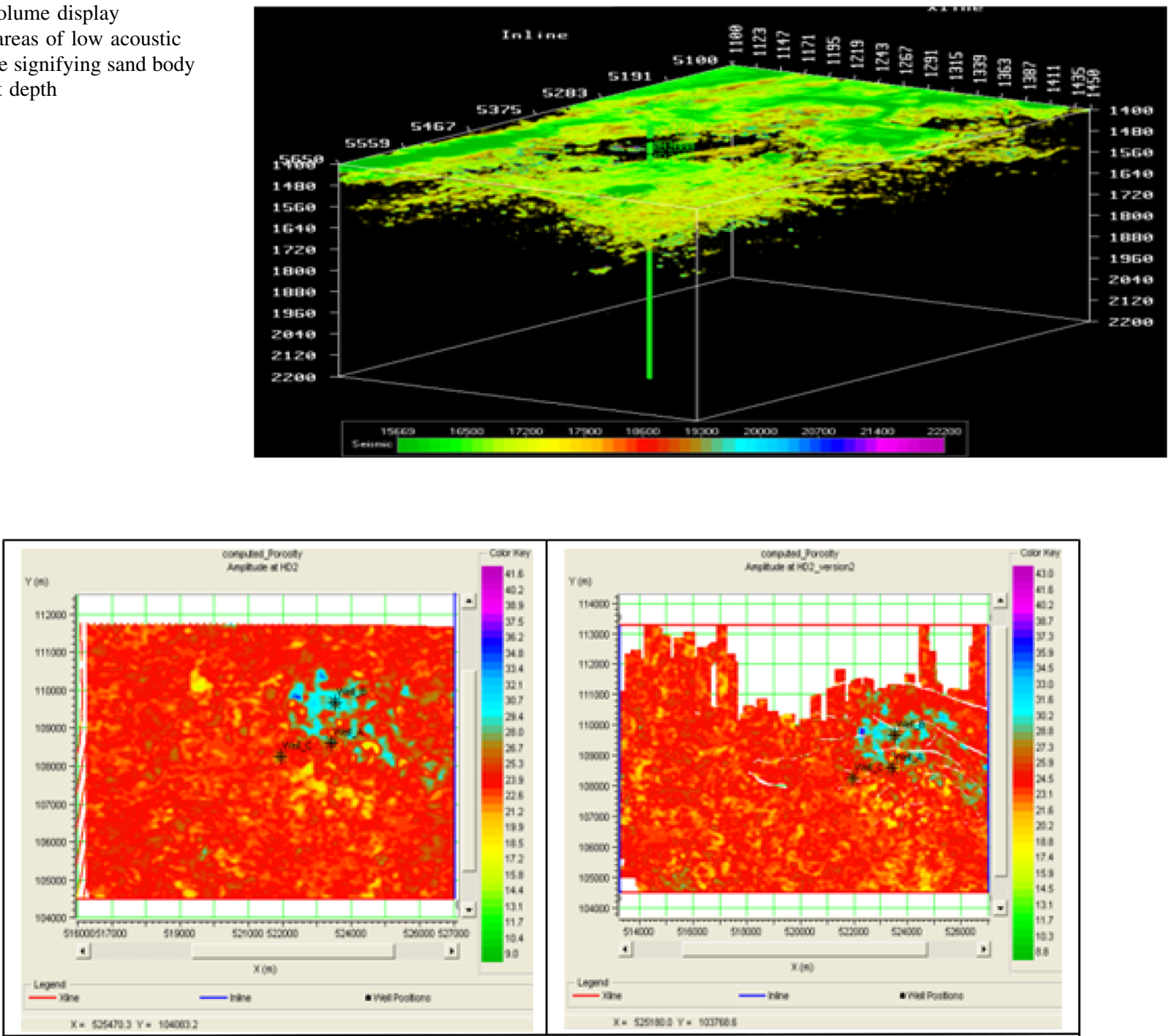

a

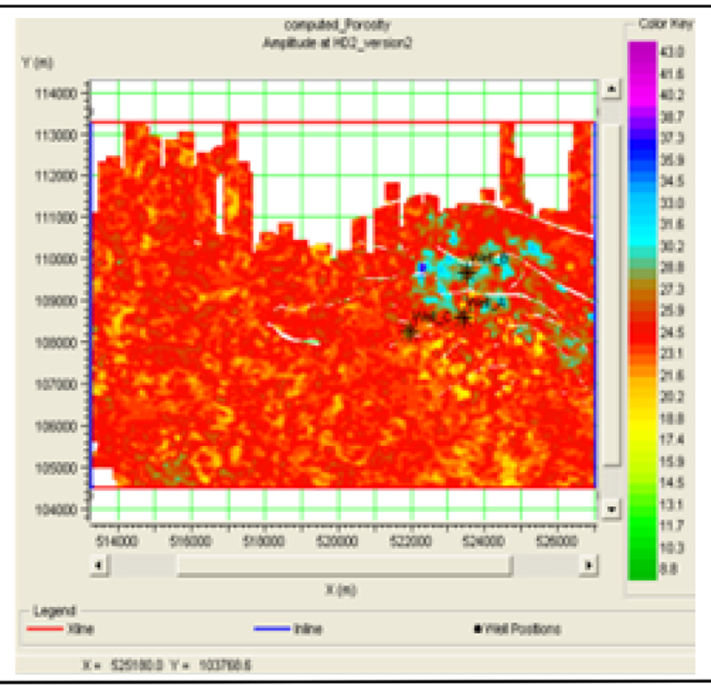

b

Fig. 10 a Computed porosity (amplitude at HD2). b Computed porosity (amplitude at HD2_version2) 


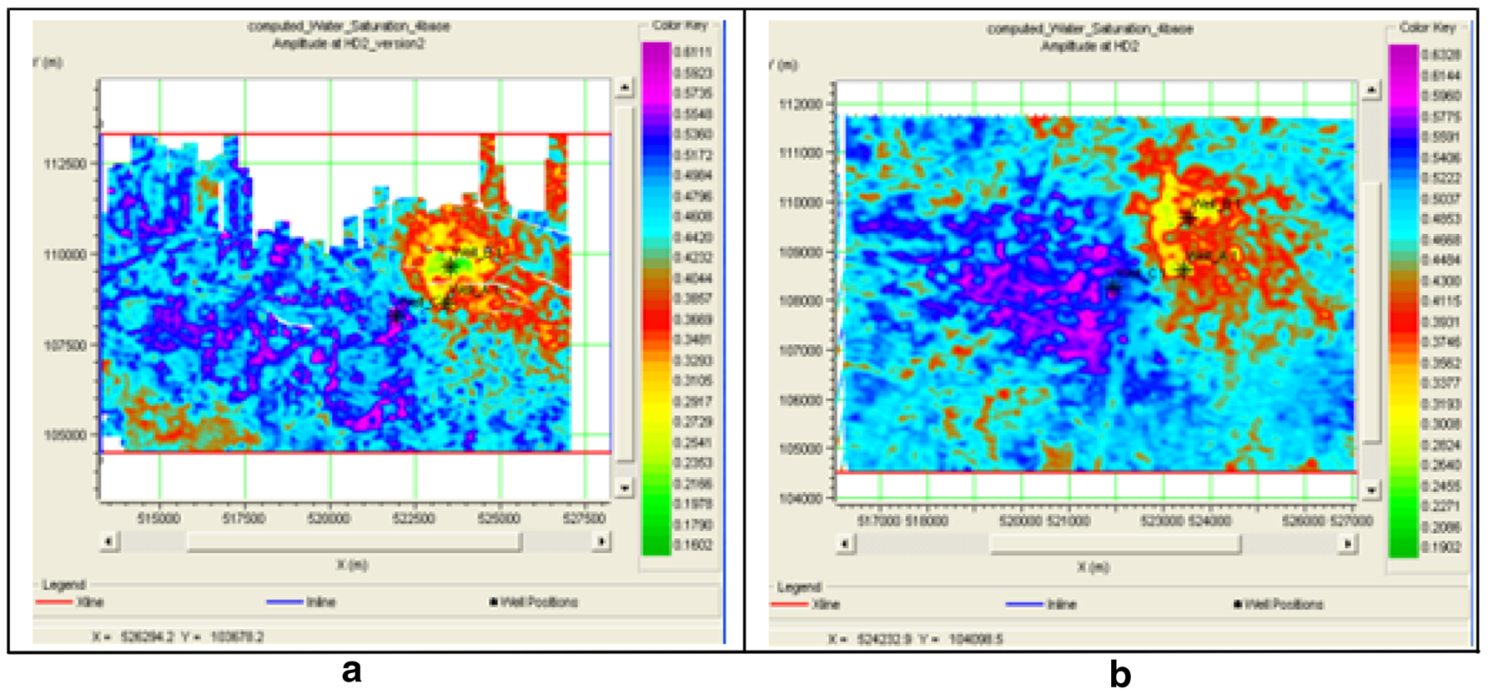

Fig. 11 a Computed water saturation (amplitude at HD2_version2). b Computed water saturation (amplitude at HD2)

Table 3 Results of Oil Volume Estimates for delineated Reservoir HD2000

\begin{tabular}{lllllllll}
\hline & $\begin{array}{l}\text { Area } \\
{\left[\mathrm{m}^{2}\right]}\end{array}$ & $\begin{array}{l}\text { Thickness } \\
{[\mathrm{ft}] \mathrm{m}}\end{array}$ & $\begin{array}{l}\text { Rock } \\
\text { volume }\left(V_{\mathrm{R}}\right)\end{array}$ & $\begin{array}{l}\text { Effective } \\
\text { porosity }(\varphi)\end{array}$ & $\begin{array}{l}\text { Pore } \\
\text { volume }\left(V_{\mathrm{P}}\right)\end{array}$ & $\begin{array}{l}\text { Water } \\
\text { saturation }\left(S_{\mathrm{W}}\right)\end{array}$ & $\begin{array}{l}\text { Hydrocarbon } \\
\text { saturation }\left(S_{\mathrm{HC}}\right)\end{array}$ & $\begin{array}{l}\text { Hydrocarbon [oil] } \\
\text { in place }[\text { barrels }]\end{array}$ \\
\hline $\mathrm{HD} 2000$ & $5,290,000$ & $(400) 121.92$ & $644,956,800$ & 0.31 & $199,936,608$ & 0.35 & 0.65 & $776,545,418.22$ \\
\hline
\end{tabular}

Fig. 12 Typical seismic session showing horizon and faults across inline

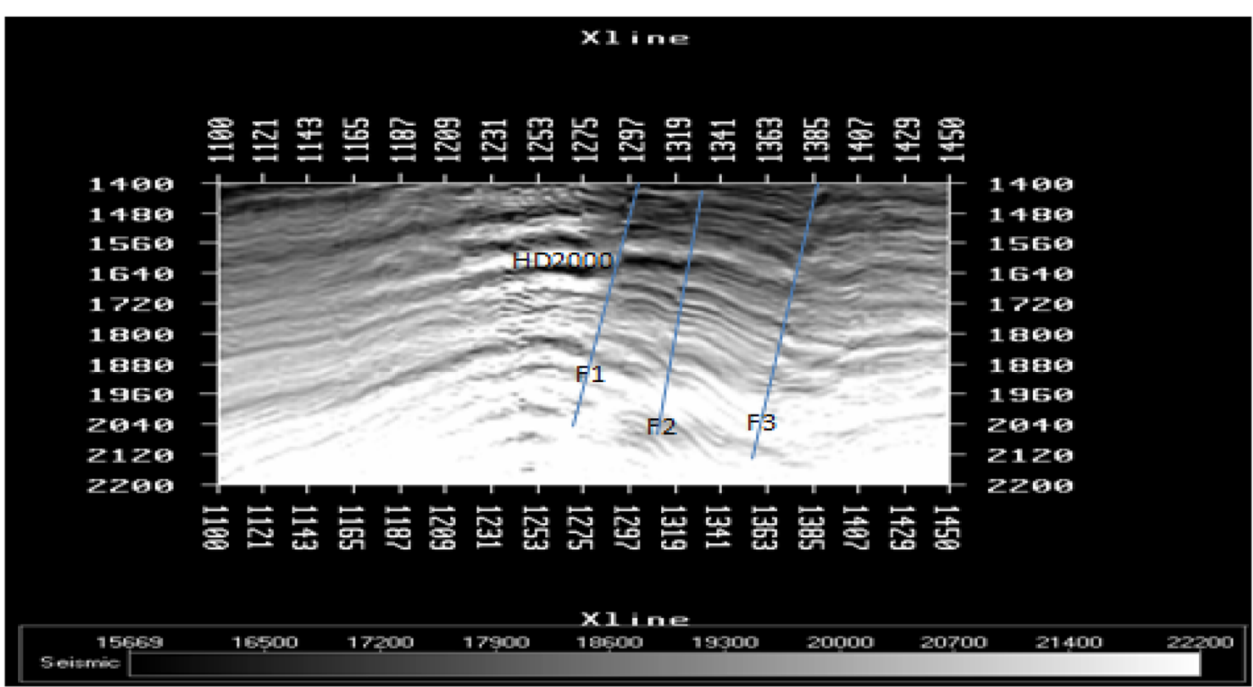

(they matched bright spots on seismic sections). The reservoir area extent estimation from the square grid method revealed that reservoir HD2000 covered an area of $5.29 \mathrm{~km}^{2}$. The detailed analysis is shown in Table 3 .

Structural interpretation

A comprehensive geologic study of the prospect is necessary to increase the confidence and reliability of determined reservoir properties such as volume, porosity, and fluid saturations. Horizon and fault interpretations were carried out for subsurface structural interpretation. In all, a formation with marker HD2000 and three visible faultsF1, F2 and F3 - were mapped on seismic sections over the entire field (Fig. 12). Growth faulting dominates the structural styles which are interpreted to be triggered by slope instability. These faults form a back to back fault system that was interpreted to be walls or ridges of mobile shale piercing upward from beneath the depobelt. It displays no growth and it is a compensating fault for overburden extension. Regular spacing and simplicity of the structures is in line with the structural styles that 
characterize the depobelt of the Niger Delta rich hydrocarbon province (Rotimi et al. 2004). The productivity of a reservoir is determined through the identification of valid structural traps within which there exists a viable reservoir.

The fault interpretation revealed several faults (F1, F2 and F3) which were mapped on the seismic sections and 3-D view representation of the reservoir, that corresponds to the growth and antithetic faults that exist on seismic section in Fig. 12. The possible petroleum trapping systems are the large roll over anticlines on the hanging wall of the thrusts which appears as dip-closed structures. Some of the closures have a dependency on fault components. In developing the structural pattern, 3-D imaging allows clear information upon which to base the faulting system (Fig. 13).

The principal structure responsible for hydrocarbon entrapment in the field is a structural high located at the center of the field which probably corresponded to the crest of the roll over structure observed on the seismic sections. This was observed as fault assisted closures on the time structure map of the horizon. Structural highs are observed in the northeast and in the center of the field while structural lows are observed in the southwest. Faults
F1, F2, and F3 act as good traps for the hydrocarbon accumulations in the reservoir at the center of the field. Also the fault on the inline corresponds to lines on the time (or depth) slice.

\section{Discussion}

The results of the study has shown the effectiveness of the estimation techniques in the lateral prediction of reservoir properties, discriminating litho-fluid and determining the porosity, saturation, net-to-gross ratio, and moreover the reserve volume. Well-to-seismic tie revealed that hydrocarbon-bearing reservoirs were associated with direct hydrocarbon indicators (bright spots and dim spots) on the seismic sections. Several faults were mapped out from the two studied horizons. This was used in generating the time structure maps. From the maps, it was observed that the principal structure responsible for hydrocarbon entrapment in the field was the anticlinal structure at the center of the field which tied to the crest of the rollover structure seen on the seismic sections. Check shots from the control well were used to create a velocity model from which the time

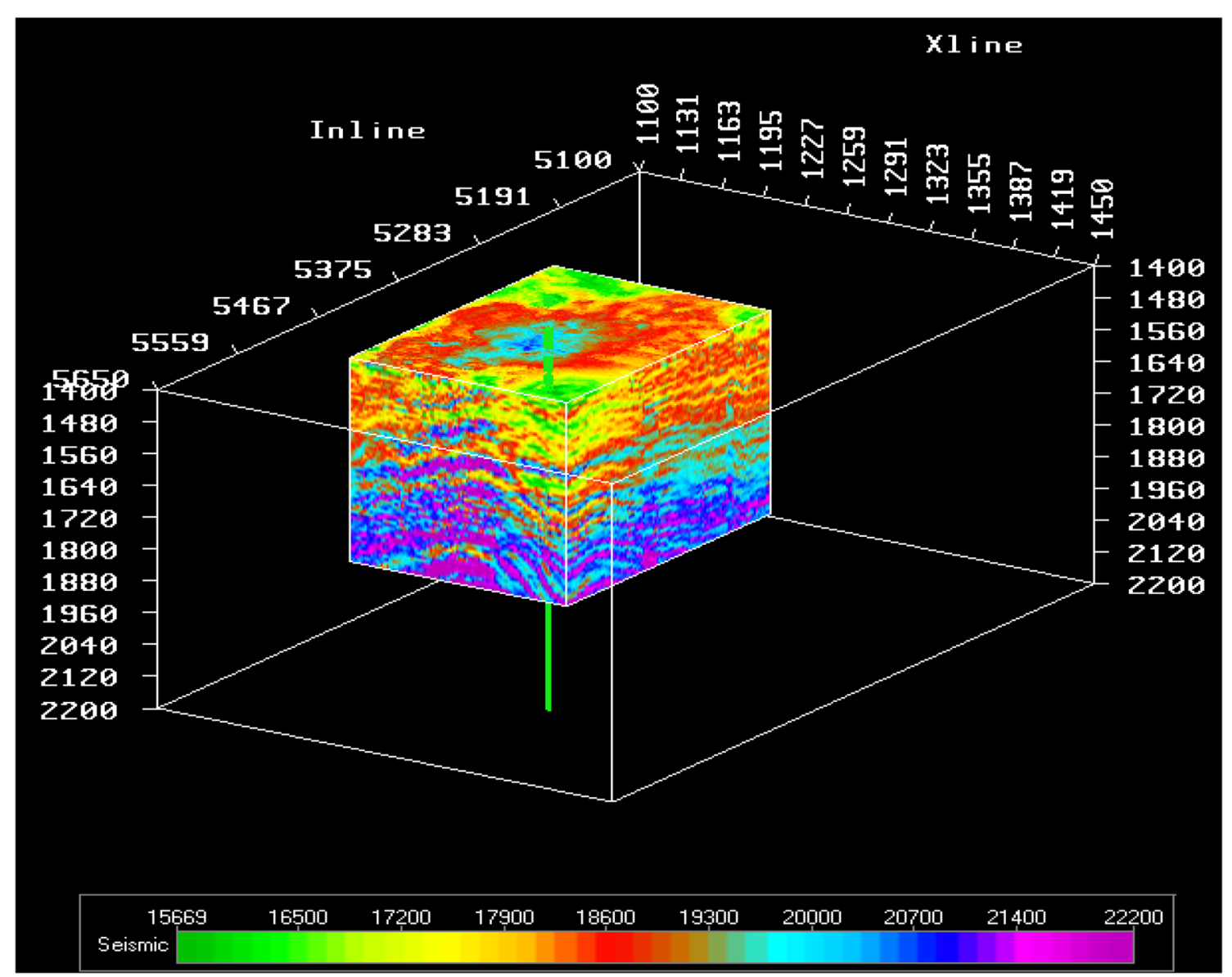

Fig. 13 3-D volume display of the reservoir area 
to depth conversion was made. Horizon slice taken shows that the reservoir spans a thickness of $400 \mathrm{ft}$.

Direct hydrocarbon indicators were used to map the reservoir boundary. They were seen on the reflection amplitude maps as high amplitude zones (bright spots) and low amplitude zones (dim spots). Reservoir area extent estimated from square grid template method revealed that reservoir HD2000 had an area estimate of $5.29 \mathrm{~km}^{2}$. Hydrocarbon saturation varied between 0.64 and 0.65 , while effective porosity varied between 0.31 and 0.32 . These computed porosity values are consistent with what some authors have reported for the Niger Delta (Aigbedion et al. 2011; Edwards and Santogrossi 1990; Olowokere and Ojo 2011).

\section{Conclusion}

Reservoir characterization in the Niger Delta has led to a better understanding of subsurface structures which in turn has immensely helped delineate reservoirs, predict reservoir properties, and minimize cost.

The integration of well and seismic data has provided insight to reservoir hydrocarbon volume which may be utilized in exploration evaluations and in well bore planning. The application of seismic inversion technology has resulted to better reservoir definition, improved resource estimates, and better reservoir management. Estimation of the volume of hydrocarbon in place revealed that the reservoir contained an estimate of 776545418.22 barrels of hydrocarbon.

Acknowledgments The authors are grateful to Shell Petroleum Development Company (SPDC) Port Harcourt for providing the data set used for this research work. We also gratefully acknowledge Hampson Russel for granting licenses to use their analysis software in this study.

Open Access This article is distributed under the terms of the Creative Commons Attribution License which permits any use, distribution, and reproduction in any medium, provided the original author(s) and the source are credited.

\section{References}

Aigbedion I, Aigbedion HO (2011) Hydrocarbon volumetric analysis using seismic and borehole data over Umoru field, Niger DeltaNigeria. Int J Geosci 2:179-183
Aly SA (1989) Evaluation of petrophysical properties of reservoir rocks using well logging analysis in Abu Ghyaradig Basin, Western Egypt. Unpublished Ph.D. thesis, Faculty of science, kain Shams University, Cairo, Egypt

Avbovbo AA (1978) Tertiary lithostratigraphy of Niger Delta. Am Assoc Pet Bull 62:295-300

Bilotti F, Shaw JH (2005) Deepwater Niger Delta fold and thrust belt modeled as a critical-taper wedge: the influence of elevated basal fluid pressure on structural styles. AAPG Bull 89(11):1475-1491

Edwards JD, Santogrossi PA (1990) Summary and conclusions. In: Edwards JD, Santogrossi PA (eds) Diverjent/Passive Margin Basins. AAPG Memoir 48. AAPG Tulsa, pp 239-248

Etu-Efeotor JO (1997) Fundamentals of petroleum geology. AfricanaFep Publishers, Onitsha, Nigeria, pp 111-123

Evamy BD, Harembourne J, Kamerling P, Knaap WA, Molley FA, Rowlands PH (1978) Hydrocarbon habitat of the tertiary Niger Delta. AAPG Bull 62:1-39

Ihianle OE, Alile OM, Azi SO, Airen JO, Osuoji OU (2013) Three dimentional seismic/well logs and structural interpretation over ' $\mathrm{X}-\mathrm{Y}$ ' field in the Niger Delta area of Nigeria. Sci Technol 3(2):47-54. doi:10.5923/j.scit.20130302.01

Klett TR, Ahlbrandt TS, Schmoker JW, Dolton JL (1997) Ranking of the world's oil and gas provinces by known petroleum volumes. U.S. Geological Survey Open-file Report-97-463. CD-ROM, pp 56-58

Kulke H (1995) Regional petroleum geology of the world. Part II: Africa, America, Australia and Antarctica, Berlin Gebruder Borntraeger, pp 143-172

Merki PJ (1970) Structural geology of the Cenozoic Niger Delta. J Geol 2(3): 10

Olowokere MT, Ojo JS (2011) Porosity and lithology prediction in Eve Field, Niger Delta using compaction curves and rock physics models. Int J Geosci 2:366-372

Owoyemi AO, Willis (2006) Depositional patterns across syndepositional normal faults, Niger Delta, Nigeria. J Sediment Res 76:346-363

Rotimi OJ Ameloko AA Adeoye OT (2004) Int J Basic Appl sci IJBAS-IENS, 10

Short KC, Stauble AJ (1967) Online of the geology of the Niger Delta. Am Assoc Petro Geol Bull 51:761-779

Weber KJ, Daukoru EM (1975) Petroleum geology of the Niger Delta. Proceedings of the 9th World Petroleum Congress. Geology Applied Science Publishers, Ltd., London (2):210-221

Whiteman AJ (1982) Nigeria: Its petroleum geology: resources and potential $1 \& 2$. Graham and Trottan, London, p 394 